\title{
SURAT PERNYATAAN
}

Dengan hormat,

Kami memerlukan konfirmasi Saudara dengan menandatangani dan mengembalikan pernyataan di bawah ini.

Penulis menjamin bahwa artikel adalah karya asli penulis dan belum pernah dipublikasikan sebelumnya. Penulis juga menjamin bahwa artikel tersebut tidak mengandung pernyataan yang memfitnah atau melanggar hukum dan tidak melanggar hak orang lain. Jika artikel dipersiapkan bersama, penulis setuju untuk memberi tahu rekan penulis ketentuan perjanjian dan untuk menandatangani atas nama mereka.

Editor,

Saya menyatakan bahwa naskah dengan

\begin{tabular}{|l|r|l|}
\hline Judul & $:$ & $\begin{array}{l}\text { Analisa rezim sedimentasi waduk studi kasus: } \\
\text { Waduk Kedungombo dan Waduk Sermo }\end{array}$ \\
\hline Nama Penulis Pertama & $:$ & Indri Rahmandhani Fitriana \\
\hline Nama/Alamat Instansi & $:$ & Universitas Gadjah Mada \\
\hline Nama Penulis Kedua & $:$ & Djoko Legono \\
\hline Nama/Alamat Instansi & $:$ & Universitas Gadjah Mada \\
\hline Nama Penulis Ketiga & $:$ & Heriantono Waluyadi \\
\hline Nama/Alamat Instansi & $:$ & Universitas Brawijaya \\
\hline
\end{tabular}

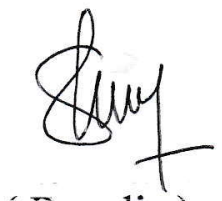

( Penulis ) 